\title{
ALIH KODE DAN CAMPUR KODE DALAM INTERAKSI IBU-IBU WARGA DESA PANTAI BAKTI KABUPATEN BEKASI
}

\author{
Fitri Anggraini $^{1}$ \\ Universitas Singaperbangsa Karawang1 \\ Fitri1812anggrainiaini@gmail.com \\ Sinta Rosalina ${ }^{2}$ \\ Universitas Singaperbangsa Karawang ${ }^{2}$ \\ sinta@fkip.unsika.ac.id
}

\begin{abstract}
ABSTRAK
Alih kode dan campur kode terjadi karena adanya interaksi dua orang atau lebih pada percakapan atau sebuah obrolan yang berbeda bahasanya. Penelitian ini akan mengkaji bentuk dan faktor "Alih kode dan Campur kode dalam Interaksi Ibu-Ibu Warga Desa Pantai Bakti Kabupaten Bekasi". Tujuan penelitian ini adalah (1.) Mendeskripsikan bentuk alih kode dalam interaksi Ibu-ibu Warga Desa Pantai Bakti Kabupaten Bekasi (2.)Mendeskripsikan bentuk campur kode (3.) Mendeskripsikan faktor penyebab terjadinya alih kode dan campur kode dalam interaksi ibu-ibu warga Desa Pantai Bakti Kabupaten Bekasi. Penelitian ini menggunakan metode pendekatan kualitatif. Teknik pengumpulan data pada penelitian ini adalah menggunakan teknik, rekam, catat dan simak. Teknik analisis pada penelitian ini Peneliti merekam secara tidak langsung pada percakapan ibu-ibu yang berada di Desa Pantai Bakti Kabupaten Bekasi untuk mendapatkan bentuk laih kode dan campur kode serta faktornya. Kemudian peneliti menyimak rekaman tersebut yang kemudian dicatat berdasarkan kelompoknya untuk dijadikan penelitian. Peneliti melakukan analisis data terhadap pengelompokkan data tersebut. Data penelitian ini berupa tuturan interaksi ibu-ibu warga Desa Pantai Bakti Kabupaten Bekasi. Hasil analisis data penelitian dalam interaksi ibu-ibu Desa Pantai Bakti Kabupaten Bekasi dapat dibagi menjadi beberapa bagian dari bentuk alih kode dan campur kode serta faktornya, yaitu Intern, Ekstern,campur kode campuran, campur kode ke luar, mitra tutur,sekeda bergengsi, penutur, membangkitkan humor, sikap penutur, dan berlatar belakang kebahasaan.
\end{abstract}

Kata kunci : alih kode, campur kode, interaksi

\section{A. PENDAHULUAN}

Bahasa merupakan sistem arbriter yang digunakan manusia untuk berkomunikasi. Manusia saling memahami satu sama lain dari bahasa yang diucapkannya. Interaksi terjadi karena adanya bahasa yang dimiliki oleh manusia. Namun, setiap wilayah memiliki bahasa yang berbeda-beda. Tetapi, perbedaan bahasa tersebut tidak menjadikan permasalahan yang cukup besar, karena dari perbedaan bahasa yang dimiliki masyarakat dapat mempelajari lebih dari satu bahasa. Pada saat ini teknologi secara tidak langsung sangat berdampak pada penggunakaan bahasa yang dimiliki oleh manusia. Menurut Poedjosoedarmo (dalam Maria Kiki, 2018: 21) batasan kode sebagai suatu sistem yang penerapan unsur bahasanya 
mempunyai ciri-ciri khas sesuai dengan latar belakangi penutur, relasi penutur dengan mitra tutur dan situasi tutur yang ada. Tentu saja bahasa memiliki peran penting bagi masyarakat, dari bahasa masyarakat memahami sesuatu yang diucapkan oleh manusia.

Menurut Robert Lado (Chaer 2004:86) bahwa kedwibahasaan merupakan kemampuan berbicara dua bahasa dengan sama atau hampir sama baiknya. Beberapa variasi bahasa dapat menyebabkan terjadinya peristiwa campur kode dan alih kode. Campur kode merupakan campuran dari bahasa lain dalam suatu kalimat yang sisipannya berupa klausa, kata, idiom, frase, pengulangan kata dan ungkapan. Menurut Nababan (1984: 32), menjelaskan ketika orang mencampur dua atau lebih bahasa atau ragam bahasa dalam suatu tindak bahasa tanpa disadari hal tersebut terjadi bentuk campur kode pada tuturan. Sedangkan, alih kode merupakan interaksi bahasa yang berbeda dengan yang lain. Biasanya, Alih kode adalah peralihan dari kode ke kode yang lain. Menurut Suwito (1983: 68) Alih kode adalah peristiwa peralihan kode yang satu ke kode yang lain, jadi ketika seorang penutur pertamatama menggunakan kode bahasa A misalnya bahasa Indonesia, dan kemudian beralih menggunakan kode bahasa B misalnya bahasa Betawi atau Jawa, maka peristiwa peralihan pemakaian bahasa seperti itu disebut alih kode (code-switching). Berikut penyebab terjadinya alih kode menurut Suwito (1983: 72). Penutur, Mitra tutur, Hadirnya pihak ketiga, Membangkitkan rasa humor, Sekedar bergengsi, Terpengaruh lawan jenis sedangkan faktor penyebab campur kode Menurut Suwito, (1983: 75) berpendapat bahwa factor penyebab terjadinya peristiwa campur kode ialah berlatar belakang pada sikap penutur (attitudinal type) yaitu, untuk memperhalus ungkapan, untuk menunjukkan kemampuannya, dan perkembangan dan perkenalan budaya baru dan berlatar belakang pada kebahasaan (linguistic type) yaitu, lebih mudah diingat, tidak menimbulkan kehomoniman, keterbatasan kata, dan akibat atau hasil yang dikehendaki.

Salah satu Desa yang memiliki berbagai bahasa ini, dapat dijadikan penelitian sosiolinguistik. Terdapat Campur kode dan alih kode di KP. Kedung Bokor Da Pantai Bakti ini yaitu memiliki kurang lebih 4 bahasa di lingkungan yang sama, yaitu Jawa,Betawi, Sunda, Indonesia asli. Maka dari itu, salah satu tempat ini dapat dikatakan sebagai terjadinya campur kode dan alih kode. Biasanya, terjadi saat interaksi jual-beli, atau interaksi saat mengobrol dengan masyarakat setempat.

Penelitian sebelumnya yaitu Bintara, Saddhono dan Purwadi (2017) yang berjudul Alih Kode dan Campur Kode dalam Pembelajaran di Sekolah Menengah Pertama Kabupaten 
Gunung Kidul. Hasil penelitian yaitu bentuk alih kode dalam kegiatan belajar mengajar adalah alih kode intern dan alih kode ekstern, serta bentuk campur kode dapat dikelompokkan berdasarkan unsur kebahasaan yaitu unsur kata, frasa dan klausa, selanjutnya berdasarkan macam bahasa yaitu campur kode intern dan ekstern. Fungsi alih kode dalam kegiatan belajar mengajar antara lain untuk memberi contoh, memberi perintah, atau menghormati; dan fungsi campur kode antara lain untuk menambah informasi atau mengutip, memberi penekanan, dan memberi pujian. Alih kode dan campur kode dalam kegiatan belajar mengajar memberi dampak positif dan negatif. Hasil penelitian ini juga menunjukkan bahwa alih kode dan campur kode dalam kegiatan belajar mengajar dapat dijadikan sebagai materi ajar diskusi pada kelas 8 SMP Negeri 2 Gedangsari

\section{B. METODOLOGI PENELITIAN}

Penelitian ini menggunakan pendekatan kualitatif deskriptif. Pendekatan kualitatif adalah pendekatan yang mendeskripsikan penelitian secara rinci. Alasan peneliti menggunakan metode kualitatif deskriptif karena data yang didapatkan peneliti besumber dari studi literature atau kepustakaan yang diperoleh secara online. Metode penelitian kualitatif ini bersifat alamiah atau sesuai dengan kenyataan yang terjadi. Kemudian, analisis penelitian ini hasil data yang didapatkan berasal dari lapangan. Teknik pengumpulan data pada penelitian ini adalah menggunakan teknik, rekam, catat dan simak. Teknik analisis pada penelitian ini Peneliti merekam secara tidak langsung pada percakapan ibu-ibu yang berada di Desa Pantai Bakti Kabupaten Bekasi untuk mendapatkan bentuk laih kode dan campur kode serta faktornya. Kemudian peneliti menyimak rekaman tersebut yang kemudian dicatat berdasarkan kelompoknya untuk dijadikan penelitian. Peneliti melakukan analisis data terhadap pengelompokkan data tersebut.

\section{HASIL PENELITIAN DAN PEMBAHASAN}

Hasil analisis data penelitian dalam interaksi ibu-ibu Desa Pantai Bakti Kabupaten Bekasi dapat dibagi menjadi beberapa bagian dari bentuk alih kode dan campur kode serta faktornya, yaitu Intern, Ekstern,campur kode campuran, campur kode ke luar, mitra tutur,sekeda bergengsi, penutur, membangkitkan humor, sikap penutur, dan berlatar belakang kebahasaan.

\section{Tabel 4.1 Bentuk Dan Faktor Penyebab Alih Kode dalam Interaksi Ibu-Ibu Warga Desa Pantai Bakti Kabupaten Bekasi}




\begin{tabular}{|c|c|c|c|}
\hline No & Data Penelitian/percakapan & $\begin{array}{c}\text { Bentuk Alih } \\
\text { kode }\end{array}$ & $\begin{array}{c}\text { Faktor penyebab } \\
\text { alih kode }\end{array}$ \\
\hline 1. & $\begin{array}{l}\text { PERCAKAPAN } 1 \\
\text { B : telor semalam udah dibalikin tuh } \\
\text { A: lah piro? } \\
\text { B; Lha kuwi mau bengi gawe bakso endog } \\
\text { e kakean wong uwong e ming sitik, iwak e } \\
\text { yo ming sitik. } \\
\text { (lah itu semalam bikin bakso telur ngasinya } \\
\text { banyak banget, lah ketahuan orangnya } \\
\text { sedikit, ikannya sedikit) }\end{array}$ & Intern & Mitra Tutur \\
\hline 2. & $\begin{array}{l}\text { B: yes, ming balunge sek okeh tenan } \\
\text { ( iya, hanya tulanngya yang banyak banget) } \\
\text { A: terigu berapa terigu? } \\
\text { B: sagu bukannya terigu }\end{array}$ & Ekstern & Sekedar bergengsi \\
\hline 4. & $\begin{array}{l}\text { PERCAKAPAN } 2 \\
\text { A: iyeh pagimana ani kaga bisa-bisa, } \\
\text { pengin sinau } \\
\text { (iyah, bagaimana ani tidak bisa-bisa, ingin } \\
\text { belajar) } \\
\text { B: Nomer siji siapke ndisik bumbu } \\
\text { brambang, bawang, jahe kunyit kemangi } \\
\text { tomat uyah, micin, nek pengen legi yo } \\
\text { tambahono gulo } \\
\text { (nih, pertama siapin dulu bumbu bawang } \\
\text { merah, bawah putih jahe, kunyit, kemangi, } \\
\text { tomat, garam, mecin, kalau mau manis dikit } \\
\text { tambahin aja gula) }\end{array}$ & Intern & Sekedar bergengsi \\
\hline 4. & $\begin{array}{l}\text { PERCAKAPAN } 2 \\
\text { A: iyeh pagimana ani kaga bisa-bisa, }\end{array}$ & & \\
\hline
\end{tabular}




\begin{tabular}{|c|c|c|c|}
\hline & $\begin{array}{l}\text { pengin sinau } \\
\text { (iyah, bagaimana ani tidak bisa-bisa, ingin } \\
\text { belajar) } \\
\text { B: Nomer siji siapke ndisik bumbu } \\
\text { brambang, bawang, jahe kunyit kemangi } \\
\text { tomat uyah, micin, nek pengen legi yo } \\
\text { tambahono gulo } \\
\text { (nih, pertama siapin dulu bumbu bawang } \\
\text { merah, bawah putih jahe, kunyit, kemangi, } \\
\text { tomat, garam, mecin, kalau mau manis dikit } \\
\text { tambahin aja gula) }\end{array}$ & Intern & Sekedar bergengsi \\
\hline 5. & $\begin{array}{l}\text { PERCAKAPAN } 3 \\
\text { A: kirain ngga, tadi si tio neneknya } \\
\text { gegerowokan katanya jam berapa, jadi } \\
\text { ora } \\
\text { B: Iyo sido, diomongno ngko bar ashar } \\
\text { wae ben rodo eyup } \\
\text { ( iya, jadi bilangin nanti abis asar biar adem- } \\
\text { ademan) } \\
\text { A: iya biar resep ya } \\
\text { (iya agar suka ya) } \\
\text { B: iyeh, kalau ada mah duit seribuan buat } \\
\text { nyawer ibu-ibu ya, sarang } 2000 \text { mah } \\
\text { gampang udah pada giroh aja } \\
\text { (iya, kalau ad amah uang seribuan bbuat } \\
\text { nyawer ibu-ibu ya, masing-masing } 2000 \text { juga } \\
\text { gampang udah pada bahagia aja) } \\
\text { A; katanya mau pada beli ayam, jadi ora? } \\
\text { B: Iyo ngko podo mangan neng kono } \\
\text { (eh iya iya nanti kita pada makan di sana) }\end{array}$ & Intern & $\begin{array}{c}\text { Membangkitkan } \\
\text { humor }\end{array}$ \\
\hline 6. & A: iya makan di pakis mah kan mahal & & \\
\hline
\end{tabular}




\begin{tabular}{|l|l|l|}
\hline hahaha & Intern & Penutur \\
B: kan maen ah apalagi karang minggu & & \\
udeh orang deket ge sangkanya mah jaoh & & \\
(bukan main ah apalagi sekarang minggu & & \\
udah orang dekat juga dianggap jauh) & & \\
A: haha iya, ya sudah hayu ah siap-siap & & \\
B: hayu ah & & \\
\hline
\end{tabular}

Tabel 4.2 Bentuk dan Faktor Terjadinya Campur Kode Dalam Interaksi Ibu-Ibu Warga Desa Pantai Bakti Kabupaten Bekasi

\begin{tabular}{|c|c|c|c|}
\hline No & Data Penelitian/percakapan & $\begin{array}{c}\text { Bentuk } \\
\text { Campur Kode }\end{array}$ & $\begin{array}{c}\text { Faktor } \\
\text { Penyebab } \\
\text { Campur Kode }\end{array}$ \\
\hline 1. & $\begin{array}{l}\text { PERCAKAPAN } 2 \\
\text { A: Bun, kalau cara bikin sayur ikan } \\
\text { bumbu kuning giamana, sih, tau ngga } \\
\text { bunda? } \\
\text { B: yes i do, gampang caranye yailah } \\
\text { ( ya, tentu saja, mudah caranya ya ampun) } \\
\text { A; terus itu masukin airnya dulu kan, } \\
\text { kalau udah panas baru masukin ikannya } \\
\text { biar mateng baru dah bumbu semuanya } \\
\text { ya? } \\
\text { B: Oh no, digongso sek bumbune kabeh } \\
\text { sek wis diuleg mau, dikiro kiro wae } \\
\text { bumbune sepiro } \\
\text { (lah bukan, ada juga tumis dulu bumbu } \\
\text { semuanya yang udah digerus, dari bumbu } \\
\text { tadi itu kira-kira secukupnya aja biar enak } \\
\text { atau kerasa bumbu itu seapa aja, intinya }\end{array}$ & $\begin{array}{l}\text { Campur kode } \\
\text { campuran }\end{array}$ & Sikap penutur \\
\hline
\end{tabular}




\begin{tabular}{|l|l|l|l|}
\hline & perkiraan.) & & \\
\hline & $\begin{array}{l}\text { PERCAKAPAN 3 } \\
\text { Aah yes yes, itu bun ntar sore jadi kaga } \\
\text { (oh iya, iya, ibu bun nanti sore jadi tidak } \\
\text { anak paud jalan-jalan ke pakis? } \\
\text { B: lah yes, jadi, kan udah buat baso } \\
\text { segala macem, masa kaga jadi, kage-kage } \\
\text { aja dah pade nanya nye gomeh } \\
\text { (lah, jadi, kan sudah membuat bakso dan } \\
\text { lain-lain, masa tidak jadi, ada-ada sja itu } \\
\text { pada nanya nya) }\end{array}$ & $\begin{array}{l}\text { Campur kode } \\
\text { kelakang pada } \\
\text { sikap penutur }\end{array}$ \\
\hline 4. & $\begin{array}{l}\text { A: iya masa kata dia habis dzuhur } \\
\text { B: hahaha orang kitae bilangnye ke yang } \\
\text { lain ke dia mah ngga, dia jadi ngga tau } \\
\text { pegih kapan } \\
\text { (hahahah, orang kita bialngya ke yang lain } \\
\text { ke dia itu tidak, jadi dia tidak tahu pergi } \\
\text { kapan) }\end{array}$ & Campur kode \\
luar & Berlatar \\
belakang pada \\
kebahasaan
\end{tabular}

Berdasarkan tabel, interaksi ibu-ibu warga Desa Pantai Bakti Kabupaten Bekasi terdapat bentuk alih dan campur kode serta faktor penyebab terjadinya alih kode dan campur kode. Berikut di bawah ini akan diuraikan penjelasan dari tabel analisis data bentuk alih kode dan campur kode beserta faktor terjadinya.

\section{Bentuk alih kode}

Bentuk alih kode merupakan situasi perubahan bahasa dari satu bahasa ke bahasa yang lain. Dalam penelitian ini terdapat dua bentuk alih kode teori menurut Suwito yaitu alih kode intern dan ekstern. Dalam interaksi ibu-ibu warga Desa Pantai Bakti Kabupaten Bekasi terdapat bentuk alih kode tersebbut. Namun, pada penelitian bentuk alih kode interaksi ibu-ibu tersebut lebih banyak terdapat bentuk alih kode intern dari pada bentuk alih kode ekstern. Berikut di bawah ini akan diuraikan.

a. Alih kode intern 
Alih kode intern yang terjadi dalam interaksi ibu-ibu warga Desa Pantai Bakti Kabupaten Bekasi yaitu bahasa Indonesia ke bahasa jawa/betawi, dan bahasa Jawa/betawi ke bahasa Indonesia.

1) Alih kode intern bahasa Indonesia ke bahasa Jawa

Percakapan di atas merupakan interaksi yang terjadi pada ibu-ibu Desa Pantai Bakti Kabupaten Bekasi. Di dalam interaksi tersebut pada tuturannya menunjukan bentuk alih kode intern dari bahasa Indonesia ke bahasa Jawa. Penutur A memulai dengan bahasa Indonesia dengan tuturan "telor semalam udah dibalikin tuh"yang dijawab oleh Mitra tutur berbahasa Jawa dengan tuturan "lah piro? ", selanjutnya dijawab kembali dengan penutur dengan menggunakan bahasa Jawa dengan tuturan "Lha kuwi mau bengi gawe bakso endog e kakean wong uwong e ming sitik, iwak e yo ming sitik.". Maka dari itu, pada interaksi percakapan 1 ini menunjukan adanya bentuk alih kode yang terjadi dari bahasa Indonesia ke dalam bahasa Jawa, penutur akhirnya menyesuaikan mitra tutur yang menggunakan bahasa Jawa. Hal tersebut, sudah jelas bahwa pada data 1 percakapan 1 ini terdapat bentuk alih kode intern.

2) Alih kode intern bahasa Jawa ke dalam bahasa Indonesia

Pada data 3 percakapan 1 di atas menunjukan bentuk alih kode intern dari bahasa Jawa ke bahasa Indonesia. Penutur mengawali dengan bahasa jawa dengan tuturan "oh iyo sagu" kemudian di jawab dengan mitra tutur menggunakan bahasa Indonesia dengan tuturan "sagu ada di rumah tinggal sedikit buat ngolek mah ada" selanjutnya dijawab kembali dengan penutur dengan tuturan "emang ngga kurang seperapat?" percakapan tersebut membuktikan bahwa terjadinya bentuk alih kode intern terdapat pada data ke 3 percakapan 1.

3) Alih kode intern bahasa Betawi ke bahasa Jawa

Pada data 4 percakapan 2 terdapat bentuk alih kode intern dari bahasa betawi ke bahasa jawa. Penutur mengawali pembicaraan pada data ke 4 ini dengan menggunakan bahasa Betawi yang tuturannya "iyeh pagimana ani kaga bisa-bisa" kemudian mitra tutur menjawab dengan menggunakan bahasa Jawa yang tuturannya "Nomer siji siapke ndisik bumbu brambang, bawang, jahe kunyit kemangi tomat uyah, micin, nek pengen legi yo tambahono gulo" maka pada interaksi data ke 4 ini sudah dinyatakan jelas terdapat bentuk alih kode pada warga desa Pantai Bakti kabupaten Bekasi. 
4) Alih kode intern bahasa Betawi ke bahasa Jawa

Pada data ke 5 percakapan 3 terdapat bentuk alih kode intern sama dengan data ke 4 pada percakapan 1. Pada interaksi ini penutur mengawali dengan menggunakan bahasa Betawi yang selanjutnya dijawab menggunakan bahasa jawa. Karena pada intraksi ini terdapat beberapa bahasa yang saling dikuasai antara penutur dan mitra tutur. Maka dari itu, pada intraksi ini saling memahami apa yang dibicarakan. Pada interaksi tersebut penutur menggunakan bahasa Betawi dengan tuturan "kirain ngga, tadi si tio neneknya gegerowokan katanya jam berapa, jadi ora" kemudian dijawab dengan mitra tutur menggunakan bahasa Jawa dengan tuturan "Iyo sido, diomongno ngko bar ashar wae ben rodo eyup".

5) Alih kode intern bahasa Betawi ke bahasa Indoneisa

Pada data ke 6 percakapan 3 ini terdapat bentuk alih kode intern. Pada percakapan diawali dengan menggunakan bahasa betawi yang kemudian dijawab dengan bahasa Indonesia. Mitra tutur mengawali dengan tuturan "kan maen ah apalagi karang minggu udeh orang deket ge sangkanya mah jaoh" kemudian penutur menjawab dengan tuturan menggunakan bahasa Indonesia "haha iya, ya sudah hayu ah siap-siap"

b. Bentuk alih kode Ekstren

Dalam interaksi warga ibu-ibu desa Pantai Bakti kabupaten Bekasi terdapat alih kode Ekstern, yaitu dari bahasa inggirs dan jawa ke dalam bahasa Indonesia. Berikut akan dipaparkan alih kode Ekstern di bawah ini.

Pada data ke 2 percakapan 1 ini terdapat bentuk alih kode Ektern. Pada interaksi ini penutur menggunakan bahasa Inggris dan bahasa jawa, yang kemudian dijawab dengan mitra tutur menggunakan bahasa Indonesia. Pada awalan percakapan ini penutur memulai dengan tuturan "yes, ming balunge sek okeh tenan" kemudian dijawab dengan tuturan bahasa Indonesia "terigu berapa terigu?"

\section{Bentuk campur kode}

Campur kode merupakan terjadinya pencampuran bahasa pada tuturan seseorang. Pada interaksi warga ibu-ibu desa Pantai Bakti Kabupaten Bekasi terdapat 2 bentuk campur kode, yaitu campur kode campuran dan campur kode ke luar.

a. Bentuk campur kode campuran 
Peristiwa interaksi d atas menunjukan adanya bentuk ampur kode. Pada interaksi di atas yang terdapat pada data 1 ini termasuk dalam bentuk campur kode campuran. Interaksi campur kode campuran ini yaitu dari bahasa Indonesia, bahasa Inggris dan bahasa jawa. Pada awal tuturan penutur menggunakan bhasa Indonesia. Kemudian, mitra tutur menjawab percakapan tersebut dengan bahasa Inggris yan disisipi bahasa Jawa. Bentuk campur kode pada interaksi tersebut terdapat dalam kalimat "Oh no, digongso sek bumbune kabeh sek wis diuleg mau, dikiro kiro wae bumbune sepiro". Campur kode serupa yang terjadi pada interaksi tersebut terdapat pada data ke 7 percakapan 2 sebagai berikut.

b. Bentuk campur kode ke luar

Pada interaksi di atas terdapat bentuk campur kode ke luar pada ibu-ibu warga desa Pantai Bakti Kabupaten Bekasi. Bentuk campur kode ke luar pada percakapan ini menggunakan bahasa inggris yang disisipi dengan bahasa betawi. Awal terjadi percakapan tersebut penutur menggunakan bahasa inggris yang disisipi bahasa betawi, kemudian ditanggapi dengan mitra tutur dengan menggunakan bahasa yang sama. Berdasarkan percakapan tersebut telah terdapat bentuk campur kode ke luar. Selanjutnya pada data ke 3 terdapat bentuk campur kode serupa sebagai berikut. Bentuk campur kode ke luar pada percakapan ini menggunakan bahasa betawi yang disisipi dengan bahasa Indoensia. Awal terjadi percakapan tersebut penutur menggunakan bahasa betawi yang disisipi bahasa Indonesia, kemudian ditanggapi dengan mitra tutur dengan menggunakan bahasa yang sama. Berdasarkan percakapan tersebut telah terdapat bentuk campur kode ke luar. Selanjutnya pada data ke 4 terdapat bentuk campur kode serupa.

\section{Faktor-faktor penyebab terjadinya bentuk alih kode dan bentuk campur kode}

a. Faktor penyebab terjadinya alih kode

Faktor yang melatar belakangin terjadinya alih kode pada interaksi ibu-ibu warga Desa Pantai Bakti Kabupaten Bekasi adalah, mitra tutur, sekedar bergengsi, penutur, dan membangkitkan humor.

1. Mitra tutur

Percakapan di atas merupakan bentuk alih kode internal. Faktor penyebab terjadinya alih kode pada interaksi ini adalah mitra tutur. Pada data 1 mitra tutur 
menanggapi percakapan menggunakan bahasa jawa yang dijawab kembali dengan bahasa jawa oleh penutur. Kemudian, pada data ke 3, mitra tutur menanggapi percakapan dari penutur menggunakan bahasa Indonesia yang kemudian dijawab kembali dengan penutur menggunakan bahasa Indonesia.

2. Sekedar bergengsi

Pada data 2 dan 4 terdapat faktor yang sama, yaitu sekedar bergensi dari faktor penyebab terjadinya alih kode. Pada data ke 2 interaksi diawali dengan penutur menggunakan bahasa inggris dan jawa, kemudian ditanggapi dengan bahasa Indonesia. Pada interaksi ini terjadi faktor sekedar bergengsi karena menggabungkan beberapa bahasa pada percakapan. Sedangkan pada data 4 penutur mengawali interaksi menggunakan bahasa betawi, kemudian ditanggapi dengan mitra tutur menggunakan bahasa Jawa.

3. Penutur

Pada data ke 6 ini terdapat faktor penutur. Hal tersebut dapat dilihat bahwa pada saat interaksi penutur menggunakan bahasa betawi, kemudian ditanggapi dengan bahasa betawi dengan mitra tutur.

4. Membangkitkan humor

Pada data ke 5 ini terdapat faktor penyebab terjadinya alih kode yaitu membangkitkan humor. Pada percakapan tersebut ada interaksi yang membangkitkan atau membuat mitra tutur merasa bahagia. Pada percakapan tersebut mitra tutur mengucapkan kata “ giroh” yang dapat membangkitkan humor.

\section{Faktor penyebab terjadinya campur kode}

Faktor yang melatar belakangin terjadinya campur kode pada interaksi ibu-ibu warga Desa Pantai Bakti Kabupaten Bekasi adalah sikap penutur dan berlatar belakang pada kebahasaan.

a. Sikap penutur

Interaksi yang terjadi pada ibu-ibu warga Desa Pantai Bakti Kabupaten Muaragembong menunjukan terjadinya faktor penyebab campur kode. Faktor yang menyebabkan terjadinya campur kode ke luar adalah sikap penutur. Faktor ini terjadi karena penutur tidak memahami padanan kata frasa, kata atau klausa dalam bahasa dasar yang digunakan. Seperti kalimat" yes, ming balunge sek okeh tenan" kalimat tersebut menunjukkan adanya campur kode yaitu percampuran bahasa Inggris ke dalam 
bahasa Jawa. Sikap penutur sering menjadi faktor penyebab terjadinya campur kode, seperti contohnya yang sudah dipaparkan pada interaksi ibu-ibu warga Desa Pantai Bakti Kabupaten Bekasi.

b. Berlatar belakang pada kebahasaan

Kemampuan dalam menggunakan dua bahasa secara tidak sadar menjadikan penutur melakukan campur kode. Faktor tersebut juga terjadi pada mitra tutur yang menggunakan bahasa Sunda disisipi bahasa Indonesia. Seperti kalimat mitra tutur "yowis, emang kudu diajak pan jalan-jalan same para tetangge ini ceritanye" tuturan penutur melakukan campur kode dari bahasa jawa disisipi bahasa betawi. Jadi faktor penyebab terjadinya campur kode dalam interaksi ibu-ibu warga desa Pantai Bakti Kabupaten Bekasi, karena faktor bahasa penutur dan mitra tutur yang melakukan campur kode dari dua bahasa yang dikuasai. Penutur dan mitra tutur memiliki dua kemampuan berbahasa pada saat percakapan sedang dilakukan. Seperti pada data faktor penyebab terjadinya campur kode ini yaitu bahasa jawa, bahasa betawi, Indonesia dan bahasa inggris.

\section{SIMPULAN DAN SARAN}

Alih kode merupakan situasi perubahan bahasa dari satu bahasa ke bahasa yang lain. Dalam penelitian ini terdapat dua bentuk alih kode teori menurut Suwito yaitu alih kode intern dan ekstern. Campur kode merupakan campuran dari bahasa lain dalam suatu kalimat yang sisipannya berupa klausa, kata, idiom, frase, pengulangan kata dan ungkapan. Pada penelitian di desa Pantai Bakti Kabupaten Bekasi terdapat empat bahasa yang dikuasai oleh penutur dan mitra tutur, antara lain bahasa Indonesia, betawi, jawa dan Inggis. Namun pada penguasaan bahasa Inggris hanya saja tidak terlalu seperti penguasaan bahasa jawa, berawi, dan bahasa Indonesia. pada hasil penelitian ini terdapat faktor terjadinya alih kode dan campur kode. Pada data alih kode terdapat beberapa faktor, seperti penutur, mitra tutur, membangikatkan humor, sekedar bergengsi. Sedangkan, faktor campur kode anatar lain berlatang belakang pada sikap penutur dan berlatar belakang pada kebahasaan. Saran pada penelitian ini diharapkan penutur dapat menguasai bahasa lainnya agar berimplikasi sangat baik jika berbagai bahasa dapat dikuasai.

\section{E. DAFTAR PUSTAKA}


Lingua Rima: Jurnal Pendidikan Bahasa dan Sastra Indonesia

Vol. 10 No. 3 September 2021

http://jurnal.umt.ac.id/index.php/lgrm

Bintara, F. E., Saddhono, K. dan Purwadi. (2018). Alih Kode dan Campur Kode dalam Pembelajaan di Sekolah Menengah Pertama Kabupaten Gunung Kidul. Jurnal Basastra. Vol 5 No 1 Hal 77-91

Chaer, Abdul dan Leonie Agustina. 2010. Sosiolinguistik Perkenalan awal.

Rineka Cipta: Jakarta.

Nababan. 1984. Sosiolinguistik: Suatu Pengantar. Jakarta: Gramedia

Suandi, I. N. 2014. Sosiolinguistik. Graha Ilmu: Yogyakarta

Suwito. 1983. Pengantar Awal Sosiolinguistik Teori dan Problema. Surakarta: UNS Press.

Maria, Kiki. 2018. Alih Kode dan Campur Kode Serta Tujuannya dalam Dialog Interaktif Republik Sentilan Sentilun Metro TV. [online]. https://www.google.com/url?sa=t\&source=web\&rct=j\&url=https://repository.usd.ac.id/ 29229/2/131224027_full.pdf\&ved=2ahUKEwi9m428o_3wAhV7xDgGHRbHDHAQFj ABegQIBBAG\&usg=AOvVaw1UIwoknPvgLfgTxpKVDnyD diakses 04 Juni 2021 